\title{
ATXN2 Gene
}

National Cancer Institute

\section{Source}

National Cancer Institute. ATXN2 Gene. NCI Thesaurus. Code C124926.

This gene plays a role in receptor trafficking. 